\title{
Roch Carrier: A Québec Author in Translation
}

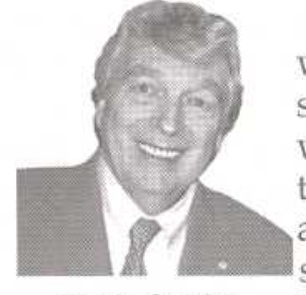

Roch Carrier

\section{Anthony Mollica}

If there ever was a short story that would appeal to young Canadian boys and stoke up a reading fren-zy, it is Roch Carrier's classic tale of The Hockey Sweater. It is filled with humorous anecdotes about a young Quebec boy who whose favourite Montréal Canadien hockey sweater (Maurice "The Rocket" Richard no less) is worn out and by mistake is replaced with a mail-order of the Toronto Maple Leaf sweater. Oh the calamity and humiliation and the adventure of it all! So too, The Basketball Player illustrates how a young boy conquers his fear to finally excel at a sport he neither likes or wants to play. Other books include The Longest Home Run, The Boxing Champion and of course The Flying Canoe featuring eleven yearold dreamer Baptiste. Published by Tundra books, these books are a must on any boy's gift list and every school library should have multiple copies.

Born in Sainte-Justine-deDorchester, Quebec, Roch Carrier is a celebrated Canadian au-

thor, playwright and master storyteller. His numerous awards include The Order of Canada and The Stephen Leacock Prize for Humour.

Carrier, Roch. The Hockey Sweater. Tundra Books, 1984.

Carrier, Roch. The hockey sweater and other stories. Anansi, 1979.

Carrier, Roch. A happy new year's day. Tundra Books, 1991.

Carrier, Roch. Prayers of a very wise child. Viking Penguin Books Canada, 1991.

Carrier, Roch. The boxing champion. Tundra,1991.

Carrier, Roch. The longest home run. Tundra Books, 1993.

Carrier, Roch. The flying canoe. Tundra Books, 1999.

Carrier, Roch. The basketball player. Tundra Books, 1996.

Carrier, Roch. Our life with the Rocket: The Maurice Richard story. Viking, 2001.

Anthony Mollica is professor emeritus, Faculty of Education, Brock University. [Ed.]

\section{Facts about Boys and Literacy and Reading}

-1our out of 10 Canadians age
16-65-representing 9 million
Canadians-struggle with low lit-
eracy. From: Statistics Canada and
the Organization for Economic Co-
operation and development (2005).
www.statscan.ca/daily

Boys are two to five times more likely than girls to have a reading disability. They also have greater difficulty overcoming it. From: Cracking the Boys Code, Jennifer Curtis, Literacy At Work, Volume 48 September 2006. The same article argues that Gender is a significant factor for both choice of reading material and reading achievement in boys and girls. www.ABC-canada.org/ ourpublications/index.asp or info@abc-canada.org

Twenty percent of adult Canadians have a serious problem dealing with printed materials, 60 percent of Canadians on social assistance have not completed high school and $42 \%$ of Native Canadians do not graduate from high school compared to 22 percent in the non native population. From: World Literacy Canada at www.worldlit.ca

Upwards of 18-40 percent of Canadian Youth depending on the region and Province do not attain minimum literacy proficiency. The same survey reports that sixty percent of immigrants have low literacy, compared with 37 percent of native-born Canadians.

Due to population growth, there are almost 1 million more people living in Canada today with low literacy skills than there were a decade ago. When those aged 66 and over are also included the proportion of the population low literacy increases to nearly one-half $(48 \%)$ or some
12 million persons aged 16 and older. From: International Adult literacy and skills survey, IALSS ( 2005) Report of the advisory Committee, Towards A Full Literate Canada. www.nald.ca/fulltext

Sixty five percent of boys surveyed in a Young Australians Reading Survey said they consider reading irrelevant. The same study reported that $75-85$ percent of at risk children with poor literacy skills were boys. www. powerof reading.com.au /the reluctant reader

Test scores from Education Quality and Accountability (EQAO), Progress in International Reading Literacy Study, (PIRLS), Programme for International Student Assessment (PISA) and School Achievement Indicators (SAIP) show that girls outperform boys in all aspects of reading and writing assessments. Furthermore some studies show that underachievement actually widens with age. From Me Read? No way www.edu.gov.on.ca 